\title{
APUNTES SOBRE INQUISICIÓN Y FEMINIDAD EN LA CULTURA HISPÁNICA
}

\author{
María Jesús Torquemada SÁnchez \\ Profesora Titular de Historia del Derecho. UCM \\ mariajesustorquemada@der.ucm.es
}

\section{RESUMEN}

Se trata de examinar algunos aspectos que conciernen a la repercusión social que tuvo en su momento el establecimiento de los tribunales inquisitoriales hispánicos. Para ello se parte de los planteamientos jurídicos que no pueden ser silenciados cuando nos referimos a una institución que nació con el cometido de administrar justicia basándose en unos criterios sólo en parte religiosos. En realidad, la Inquisición Española buscaba, sin olvidar por ello el mantenimiento de la ortodoxia católica en todos los territorios de la Monarquía, la salvaguarda de un determinado orden social. En ese escenario, todos los aspectos que definen a la persona como miembro del universo hispánico tienen su trascendencia a la hora de poner en funcionamiento la maquinaria inquisitorial. La distinción de los súbditos por razón del sexo se perfila como una de las variables que marcaban ciertas diferencias a la hora de ser aplicadas las normas generadas o asumidas por el Santo Oficio.

Palabras clave: Inquisición, mujeres, Nuevo Mundo, América, proceso, tormento, brujería, bigamia.

\section{ABSTRACT}

This study involves examining some aspects concerning the social impact the establishment of the inquisitorial Hispanic courts had at that time. This is based on the legal approaches that cannot be silenced when we refer to an institution that was created to administer justice on the basis of only partly religious criteria. In fact, the Spanish Inquisition sought to safeguard a particular social order, while intending to maintain Catholic orthodoxy in all territories of the Monarchy. Within this context, all aspects that define a person as a member of the Hispanic world are important when setting the inquisitorial machine in motion. The distinction of the subjects on the basis of their sex is seen as one of the variables that made a difference when the rules created or assumed by the Holy Office were to be applied.

Keywords: Inquisition, women, New World, America, trial, torture, witchcra$\mathrm{ft}$, bigamy.

\section{ZUSAMMENFASSUNG}

Es werden einzelne Aspekte der gesellschaftlichen Auswirkungen untersucht, welche die Errichtung der hispanischen Inquisitionsgerichte mit sich brachte. Hierzu wird von juristischen Fragestellungen ausgegangen, die nicht vers- 
chwiegen werden dürfen, wenn wir uns auf eine Institution beziehen, die zum Ziel hatte, Recht zu sprechen und sich hierbei auf Rechtsgrundsätze stützte, die nur zum Teil religiösen Ursprungs waren. In Wirklichkeit suchte die Spanische Inquisition, ungeachtet ibrer Verpflichtung gegenüber der Aufrechterbaltung der katholischen Rechtsgläubigkeit in allen Territorialgebieten der Monarchie, die Aufrechterhaltung einer sozialen Ordnung. In diesem Kontext spielen alle Aspekte, welche die Person als Mitglied der hispanischen Gesellschaft ausweisen, beim Auslösen der Inquisitionsmaschinerie eine entscheidende Rolle. Die Unterscheidung der Untertanen nach ibrem Geschlecht lässt Unterschiedskriterien erkennen, die die Inquisitionsbebörde bei der Schaffung bzw. Anerkennung der Normen zur Geltung bringt.

Schlüsselwörter: Inquisition, Frauen, Neue Welt, Amerika, Prozess, Folter, Hexerei, Bigamie.

SUMARIO: I. INTRODUCCIÓN.-II. LA MUJER EN EL ÁMBITO DEL DERECHO PENAL DEL SANTO OFICIO.-1. El delito de brujería.-2. La mujer en el confesionario: el delito de solicitación en confesión.-3. La mujer y su cuerpo ante la Inquisición: el tormento y los castigos físicos.-4. Mujer, sexo y matrimonio ante el Santo Oficio.--III. LAS MUJERES Y SU VIDA COTIDIANA ANTE LA INQUISICIÓN.-1. La mujer como beneficiaria de las ayudas sociales sufragadas por el Santo Oficio: la «Seguridad Social» de la Inquisición.-2. La mujer, la Inquisición y la moda.

\section{INTRODUCCIÓN}

En el presente trabajo vamos a utilizar la perspectiva de género, aunque sería igualmente válida cualquiera otra de carácter social, para llevar a cabo un acercamiento a lo que supuso la puesta en marcha de la institución inquisitorial en el mundo hispánico durante el Antiguo Régimen.

Varios son los aspectos que se pueden examinar al respecto. En primer lugar, no debemos perder de vista en ningún momento que la Inquisición Española era un tribunal de justicia, una institución jurídica que servía a los intereses de la Monarquía donde, a nuestro modo de ver, primaba el cometido de salvaguardar un orden social a la luz, eso sí, de un credo y una ortodoxia religiosos. Es más, como señala Gacto al referirse al proceso inquisitorial, éste y el proceso penal común no eran más que ramas de un mismo tronco extraídas de un mismo modelo, siendo los tribunales del Santo Oficio quienes observaron con mayor fidelidad las normas procesales según habían sido diseñadas por la construcción canónica y desarrolladas en el seno del Derecho común. Señala dicho autor como primera nota diferenciadora frente a otros itinerarios procedimen- 
tales existentes en el Antiguo Régimen, el acentuado legalismo del proceso inquisitorial ${ }^{1}$.

La mujer como sujeto de derechos y obligaciones representaba, claro está, la mitad de la grey sobre la cual el Santo Oficio desplegaba su actividad de vigilancia y control, existiendo determinadas peculiaridades en cuanto a su tratamiento en comparación con los varones.

Un importante factor que influía a la hora de determinar su ubicación en el universo jurídico inquisitorial venía determinado por el entorno geográfico en que se movían las féminas, vastísimos y heterogéneos territorios de aquende y allende los mares.

No siempre se nos presenta como reo cuando examinamos la casuística procesal del Santo Oficio español, pues a veces aparece la mujer como víctima, valioso testigo, esposa o amante cómplice e incluso en calidad de acreedora a ciertas prestaciones sociales directamente generadas por el aparato inquisitorial a través de su mastodóntica maquinaria administrativa.

\section{LA MUJER EN EL ÁMBITO DEL DERECHO PENAL DEL SANTO OFICIO}

A pesar de esa inicial variedad de situaciones, comenzaremos por aludir a las mujeres en sus contactos con el universo penal del Santo Oficio español.

\section{El delito de brujería}

Tenemos que empezar por reseñar la herejía femenina por excelencia: el delito de brujería. Muchísimo se podría hablar y escribir todavía acerca del mismo, a pesar de que sobre ello han corrido ya ríos de tinta. Éste es uno de los casos en que los condicionantes de tipo geográfico se hacen más patentes, existiendo el fenómeno de la brujería en su versión propia de las zonas europeas y americanas húmedas y frías, así como la relativa a las más cálidas².

${ }^{1}$ E. GaCto FernándeZ, «Observaciones jurídicas sobre el proceso inquisitorial», en A. Levaggi (coord.), La inquisición en Hispanoamérica, Buenos Aires, 1999, p. 14.

2 G. Henningsen, El abogado de las Brujas, Alianza, 2010, referente al fenómeno en tierras del norte. Sobre lo mismo pero en zonas meridionales, M. J. Torquemada SÁnchez, La Inquisición y el Diablo, Sevilla, 2000. 
Sin embargo, la Inquisición supo unificar los criterios para su persecución prescindiendo de las manifestaciones externas y buscando el elemento que diferenciaba la herejía propiamente dicha de las meras supersticiones, aunque sobre ellas también recayera el peso del aparato inquisitorial. Me refiero al pacto de adoración al demonio, expreso o implícito. En él se concretaba la herejía perfecta.

Eran las mujeres, por las razones que expone el Malleus maleficarum, las personas propensas al ejercicio de estas actividades heréticas. En este tratado se explicaba por qué las mujeres han de ser consideradas como más proclives a la práctica de las supersticiones: «Las mujeres son más crédulas y más impresionables. Aman u odian. No tienen intermedio. Tienen la lengua voluble. En una palabra, son más débiles de cuerpo y de mente [...] Toda brujería proviene del deseo carnal, del cual es insaciable la mujer [...] como consecuencia de ello es mejor denominarla herejía de las brujas que de los brujos, y bendito sea el que ha preservado al género masculino de este crimen horrendo» ${ }^{3}$. En el fondo, no se trata más que de la plasmación de la filosofía imperante desde la Roma clásica consistente en considerar jurídicamente la fragilitas o imbecillitas sexus, que se encuentra reflejada no sólo en la legislación y la práctica inquisitorial española, sino en todos los libros jurídicos anteriores a la fundación del Santo Oficio en 1478.

El delito de brujería y de supersticiones, como es notorio, tenía un tratamiento procesal diferente de otros, y la Inquisición hispana se debatía entre la incredulidad y el miedo hacia las encausadas, si bien hay que hacer constar en estas páginas que en el caso español predominó la primera sobre el segundo, a diferencia de lo que sucedió en los países germánicos y anglosajones. Aun así, se temía, por ejemplo, que el tormento fuera en ellas ineficaz al ser capaces de superarlo mágicamente con la ayuda del diablo, por lo cual no se aconsejaba su uso como modo de arrancar la confesión en esos procesos. Los medios de prueba adoptaban características grotescas que no observamos en otras figuras delictivas (pesos de brujas,

3 H. Kramer y J. Sprenger, Malleus Maleficarum, Lyon, 1569 (traducción de Floreal Mazía, Buenos Aires, Orión, 1975, p. 40). Texto original en latín: «Cur magis foeminae supersticiones reperiantur: quo ad primum cur in sexu tam fragili mulierum mayor multitudo maleficarum reperitur quam inter viros; [...] de secundo [...] (vires) de mulierum vero malitia differitur: non est ira super iram mulieris [...] tertia causa quia lubricam babent linguam. Concludamus: Omnia per carnales concupiscentiam, quae quia in eis est insatiablilis [...] Unde et consecuentes haeresis dicenda est non maleficorum, sed maleficarum, ut a patiori fiat denominatio. Et benedictus Altissimus, qui viriles speciem a tanto lagitio usque in praesens praeservat in quo utisque cum sic pro nobis nasci et pari voluit, ideo et ipsum privilegiavit». 
como en el Tribunal de Cartagena de Indias, búsqueda febril del «sapo vestido» en sus domicilios del norte de la Península, inmersión con el fin de determinar su flotabilidad, etc.).

Dirigiendo la mirada brevemente hacia el Nuevo Mundo, son bastantes las obras que los estudiosos han dedicado al fenómeno de la magia en Hispanoamérica ${ }^{4}$.

Nos encontramos con que en esos territorios el delito de supersticiones y el de brujería adquieren unos tintes diferentes a las manifestaciones peninsulares debido, principalmente, a las tradiciones indígenas y su peso en el terreno de la medicina popular. Como ha señalado Escandell Bonet, las prácticas supersticiosas se acentuaron en las Indias debido al contacto con unos aborígenes que conocían y utilizaban infinidad de plantas y elementos curativos desconocidos en el Viejo Mundo. Ello unido a las tradiciones en que se entremezclaban las ceremonias mágicoreligiosas con el uso de esas sustancias, constituía una amalgama explosiva a los ojos del Santo Oficio.

Dado que la Inquisición se inhibía normalmente cuando los sospechosos no estaban bautizados, los reos en esos procesos muchas veces eran mujeres españolas que habían sido deslumbradas por las peculiaridades de la cultura aborigen ${ }^{5}$, como en el caso de una tal Elena de la Cruz, natural de Sevilla y avecindada en Tolú (Colombia), cuya causa por brujería se siguió en el tribunal de Cartagena de Indias ${ }^{6}$.

El tabú del sexo quedaba en buena parte desvanecido ante la voluptuosidad del entorno y el clima, de modo que las mujeres perdían el pudor que las caracterizaba en la Castilla austera. Todo ello era objeto de estrecha vigilancia por parte de los tribunales inquisitoriales ${ }^{7}$.

${ }^{4}$ Citamos aquí a modo de ejemplo las obras de M. C. Navarrete, Historia social del Negro en la Colonia. Cartagena siglo XVII, Cali, 1995; D. L. Ceballos Gómez, Quien tal hace que tal pague: sociedad y prácticas mágicas en el Nuevo Reino de Granada, Bogotá, 2002; J. H. BORJa Gómez, Inquisición, muerte y sexualidad en el Nuevo Reino de Granada, Santafé de Bogotá, 1996.

5 B. Escandell Bonet, «El Tribunal peruano en la España de Felipe II», en Historia de la Inquisición en España y América, t. I, Madrid, 1984, pp. 929-930. de 1634.

AHN, Inquisición, 1620, exp. 8. Fue reconciliada en el auto de fe de 26 de marzo

7 P. Castañeda y Delgado y P. Fernández Aparicio, La Inquisición de Lima, t. II, Madrid, 1995, pp. 291-307. Tratan sobre el proceso de Ángela Carranza, mujer que presumía de ser virtuosa, y como tal se comportaba generalmente, pero en otras ocasiones salía de su casa semidesnuda y se bañaba en acequias y otros lugares sin ropa, diciendo los testigos que provocaba a los hombres. Ella, que fue tachada de visionaria, se defendía diciendo que se bañaba desnuda por sentirse abrasada «de amor divino». 
Sobre estos particulares, encontramos un interesante trabajo de Escandell en el que analiza los procesos psicológicos que atravesaban quienes, procedentes de la Península, entraban en contacto con un mundo totalmente nuevo para ellos, donde todo se agigantaba y rezumaba sensación de libertad frente al ambiente mezquino y oscurantista de la metrópoli ${ }^{8}$.

Lo cierto es que en las tierras americanas, al igual que en las peninsulares, los inquisidores no prestaron demasiada atención a las supersticiones femeninas, achacando esos comportamientos a los intentos de obtener dinero por medio de su práctica. La Suprema, lejos de lo que era la realidad social y en su permanente empeño de que la normativa se aplicara estrictamente, amonestaba a los inquisidores del Nuevo Mundo y les exhortaba a que castigaran esas conductas y aplicaran la legislación tanto inquisitorial como secular al respecto?.

\section{La mujer en el confesionario: el delito de solicitación en confesión}

También se veía comprometida la situación de las mujeres en relación con el Santo Oficio en materia sexual cuando se cometía el delito de solicitación en confesión. Este delito, atribuido estrictamente al foro inquisitorial, tuvo una mayor incidencia en esas tierras lejanas, por los mismos motivos expresados más arriba ${ }^{10}$.

Los sacerdotes, a menudo procedentes de suelo europeo, encontraban en América una mayor permisividad sexual en el seno de la sociedad, y recurrieron en ocasiones a solicitar los favores carnales de sus confesadas, aunque hay que señalar al respecto que también se han documentado solicitantes de varones ${ }^{11}$.

El papel de las mujeres denunciantes era crucial a causa de la situación de intimidad en que se cometía esa provocación, sin olvidar que durante el funcionamiento de la Inquisición el prestigio del clero difícilmente se ponía en entredicho, y era preciso hacer un considerable acopio de valor para denunciar a los confesores, sobre todo porque una sola acusación

8 B. EsCANDELl Bonet, op. cit., t. III, pp. 5-40.

9 P. Castañeda y Delgado y P. Fernández Aparicio, op. cit., t. II, pp. 336-349.

${ }^{10}$ Ibid., pp. 359 y ss.

${ }^{11}$ Este delito ha sido tratado por R. Millar Carvacho, «La Inquisición de Lima y el delito de solicitación», en La Inquisición en Hispanoamérica, op. cit., pp. 105-208. También le ha dedicado una monografía referida al Tribunal de Sevilla J. A. Alejandre García, El Veneno de Dios, Madrid, 1998. 
no incoaba el proceso, sino que la práctica inquisitorial requería al menos tres. Además, la permanente sospecha contra la fragilitas sexus implicaba hacer averiguaciones accesorias a terceras personas de contrastada probidad acerca de la fiabilidad testifical de las presuntas víctimas.

Las así acosadas solían declarar a otro sacerdote en confesión que habían sido solicitadas, y rara vez acudían directamente ante el Santo Oficio, ya sea por temor o por ignorancia. Era ese confidente quien debía advertirles que tenían obligación de denunciar, pues si no lo hacían se les negaría la absolución.

En América, el indigenismo predisponía a ciertos clérigos desaprensivos para cometer semejantes abusos ante la idea de que esas mujeres aborígenes se comportaban con mayor liberalidad en materia sexual ${ }^{12}$.

En otro orden de cosas, y dentro de la dinámica de los procesos que se siguieron contra las mujeres, a veces existía una discriminación positiva por razón del género.

\section{La mujer y su cuerpo ante la Inquisición: el tormento y los castigos físicos}

Aunque la normativa inquisitorial nunca reflejó abiertamente dichas ventajas, esa relativa lenidad se debería en buena medida a una práctica inveterada por la actuación cotidiana de los inquisidores, de la cual se desprendía que convenía ser más benévolos con los cuerpos femeninos a la hora de aplicar el tormento.

En materia de tortura volvemos a observar que la actuación inquisitorial se separaba de la llevada a cabo en los procesos penales ordinarios, pues en el juicio de Inquisición la prueba del tormento se practicaba solamente en el momento previsto para ello conforme a Derecho, que no era sino al final del periodo probatorio y siempre con carácter complementario o subsidiario.

La Inquisición lo reservaba estrictamente para los casos en que otro tipo de pruebas no arrojaran un resultado satisfactorio acerca de la inocencia o culpabilidad del reo, con la finalidad explícita de arrancar una confesión, que era otro de los medios de prueba dignos de ser tenidos en cuenta

12 J. Toribio Medina, El Tribunal del Santo Oficio de la Inquisición en las Provincias del Plata, Santiago, 1989, p. 125, citado por R. Millar Carvacho, La Inquisición en Hispanoamérica, op. cit., p. 143. 
por los inquisidores ${ }^{13}$. Esa restricción del tormento y su reserva para casos muy concretos se desprendía también de lo que aconsejaban algunos tratadistas del proceso inquisitorial, cual es el caso de Jacobo de Simancas, quien advertía de los peligros e injusticias que acarreaba el uso indiscriminado de la tortura en el marco de las preceptivas actuaciones procesales ${ }^{14}$. De hecho, son pocos, aunque llamativos, los procesos en los cuales las mujeres eran sometidas a tormento, si bien son muchos aquellos en los que se las amenazaba con el mismo.

La realidad en los tribunales seculares era muy diferente, pues los reos solían ser atormentados inmediatamente después de su captura si es que no confesaban nada más ser detenidos.

También los médicos del Santo Oficio modulaban y moderaban cierto tipo de torturas cuando la reo era una mujer, como en el caso de la toca, aconsejando un número menor de jarros o menos vueltas de cordel en el potro.

Una vez finalizado el proceso y dictada la correspondiente sentencia condenatoria, volvemos a encontrar diferencias con los varones en cuanto a los castigos procedentes. La pena de galeras no se aplicaba a las mujeres, y encontramos con frecuencia, sobre todo en el siglo XviII y comienzos del XIX, figuras punitivas consistentes en lo que hoy denominaríamos «trabajos forzados» de naturaleza social para las mujeres castigadas por la Inquisición. Éstos solían traducirse en la reclusión de las mismas en hospitales u hospicios para que llevaran a cabo tareas de limpieza, ayuda en la cocina, etc. En otros casos, y en atención al estatus de las penitenciadas, se las condenaba a reclusión en un convento.

También constatamos que los castigos físicos que comportaban la exposición de las reos a la pública vergüenza, como la pena de azotes con el torso descubierto según se practicaba en los primeros tiempos de la existencia del Santo Oficio, se fue dulcificando para las mujeres con el paso del tiempo, en el sentido de preferirse su aplicación estando la reo vestida de cintura para arriba con el fin de evitar el escándalo. A partir del siglo XviII es muy difícil encontrar la ejecución pública de la susodicha pena de azotes.

Todo lo mencionado las diferenciaba procesalmente de los varones en el universo inquisitorial.

13 E. GaCto FernándeZ, op. cit., p. 17.

${ }^{14} \mathrm{~J}$. DE SimANCAS, De catholicis institutionibus liber, ad praecavendas et extirpandas baereses admodum necessarius, Roma, 1573, p. 497: «iudices omnes bortamur, ut ante oculos Deum babentes, neminem prius torqueant, quam id fieri iura permittant [...] inde enim facile sit, ut innocens male torqueatur, et extorta falsa confessione, multo peius iniustiusque damnetur». 


\section{Mujer, sexo y matrimonio ante el Santo Oficio}

Qué decir de lo tocante al estricto control que ejercía el Santo Oficio español sobre la vida sexual de sus administrados. Las mujeres, esos oscuros objetos del deseo, aparecían ante la mirada inquisitorial como sujeto activo y pasivo de pecado y herejía.

Hay que aclarar al respecto que la Inquisición nunca prestó demasiada atención al comportamiento sexual pecaminoso y consciente por parte de los bautizados. Ello era más bien tema de confesionario. El peligro radicaba en esos comportamientos sexualmente disolutos cuando quienes los practicaban pensaban que eran correctos a los ojos de la ortodoxia religiosa. Y no se trataba de actitudes de cinismo por parte de los fieles, pretendiendo ser ignorantes de que algo era ilícito cuando obviamente todo el mundo conocía cuál era la recta doctrina en materia de prácticas sexuales. En realidad eran tiempos confusos al respecto. Las relaciones sexuales mantenidas fuera del matrimonio no se perseguían per se, sino en cuanto indicio de herejía. No olvidemos, por poner un ejemplo, que el dogma de la Inmaculada Concepción data de mediados del siglo XIX, fecha relativamente reciente.

Otro de los delitos del foro inquisitorial que implicaban directamente a las mujeres, aunque en la mayoría de los casos en calidad de sujetos pasivos, era el de bigamia.

Las necesidades sexuales de los varones cuando llevaban a cabo grandes viajes, como en el caso de quienes marchaban para hacer fortuna en el Nuevo Mundo, a veces los inducían a incurrir en delito de bigamia, que llegaría a ser considerado de mixto fuero ${ }^{15}$ por lo que suponía de amenaza frente a la recta valoración del sacramento del matrimonio y porque también atentaba contra un orden social basado en la monogamia.

Si se atribuyó también su persecución y castigo a la Inquisición fue, por supuesto, ante la necesidad de averiguar, a lo largo del proceso correspondiente, si el bígamo o la bígama pensaban que el sacramento se podía celebrar con varias personas en vida de las mismas sin incurrir en heterodoxia.

${ }^{15}$ M. Torres Aguilar, «Algunos aspectos del delito de bigamia en la Inquisición de Indias», en A. LevaGgI (coord.), La Inquisición en Hispanoamérica, op. cit., pp. 65-103. El autor se refiere en las pp. 80-81 a la naturaleza mixta de este delito. También el autor se ha ocupado del mismo con anterioridad en el ámbito del tribunal sevillano dentro de su trabajo «El delito de bigamia. Estudio general y especial perspectiva en el Tribunal de la Inquisición de Sevilla en el siglo XviII», en E. Gacto FernándeZ (ed.), El Centinela de la Fe, Sevilla, 1997, pp. 173-232. 
Las Indias eran el escenario ideal para la comisión de ese delito por la facilidad que la distancia otorgaba a quienes querían borrar su pasado y, con él, las obligaciones conyugales contraídas anteriormente en otras tierras lejanas.

Muchas eran las circunstancias que empujaban a quienes viajaban hasta América para incurrir en bigamia, como por ejemplo el deseo de iniciar una nueva vida en un lugar lejos del hogar donde ya no se pensaba poder regresar, la sospecha de que la falta de noticias respecto al anterior cónyuge pudiera implicar su fallecimiento, etcétera ${ }^{16}$.

Por todo ello, no siempre hay que atribuir este tipo de conductas a la picaresca de los sujetos que en ellas incidían, pues se han documentado multitud de casos en que el abandono de la esposa previa para contraer nuevas nupcias se llevaba a cabo bajo la sincera creencia de que en un marco diverso y distante el matrimonio anterior se difuminaba, quedando de alguna manera invalidado. En esos supuestos resultaba muy complicado determinar la existencia de herejía durante el proceso inquisitorial.

Lo cierto es que las víctimas sociales, en esos casos, eran las esposas, tanto la legítima como la reputada como tal sin serlo, conjuntamente con la prole que pudiera haberse derivado de esas convivencias sucesivas o simultáneas.

Pero no siempre era la mujer de procedencia indígena quien resultaba abandonada y olvidada desde que el esposo regresaba a la Península y contraía nupcias nuevamente. En otras tantas ocasiones el fenómeno se producía a la inversa, cuando los maridos se embarcaban hacia el nuevo continente dejando atrás esposa e hijos.

La legislación indiana intentaba salir al paso de esos abandonos, demasiado frecuentes a juzgar por los documentos, y establecía con carácter general que los casados no podían pasar de la metrópoli a las Indias sin su mujer, y el férreo control de las autoridades para evitar los casos de bigamia entre los que iban y venían a tierras americanas se había plasmado en disposiciones anteriores al establecimiento de los tribunales inquisitoriales indianos ${ }^{17}$. Pero existen casos documentados en los que esa obligación se incumplía ${ }^{18}$.

${ }^{16}$ Ibid., p. 79.

${ }_{17} \mathrm{Ibid}$., p. 78. Señala el autor que ya en 1534 se promulgó una ley que sería reiterada en 1565, 1569 y 1579, pasando a incorporarse luego a la recopilación de 1680, así como otras tendentes también a que se cumpliera la convivencia marital en Indias y se hicieran averiguaciones acerca del estado civil de quienes constaran como casados en esas tierras. De hecho, la Recopilación de Indias de 1680, VII, III, dedica este título completo a esos problemas bajo el epígrafe: «De los casados y desposados en España, é Indias que estan ausentes de sus mugeres y esposas». Incluso a lo largo del siglo xviII sería necesario ir completando y actualizando esas normas.

${ }_{18}$ M. J. Torquemada SÁncheZ, «Esposas y amantes en el ámbito de la Inquisición», en Cuadernos de Historia del Derecho, núm. 2, Madrid, 1995, pp. 253-263. 
Hemos examinado algún supuesto rocambolesco en el cual el esposo, llegado el momento de viajar a las Indias para buscar fortuna, no sólo dejó tras de sí en la Península a su esposa e hijos, sino que la depositó expresamente en manos de un amigo, diciéndole a éste de forma muy explícita que «le quedaba por mujer», al parecer en virtud de una contrata realizada entre el viajero y su amigo a cambio de diez mil pesos para los gastos de viaje del primero. A tenor de los documentos, nada opuso la esposa ante la nueva situación, y de hecho, cuando regresó el marido más pobre de lo que partió, ella había tenido varios hijos con su amante «forzoso», a la sazón familiar del Santo Oficio, y consta, a tenor de los autos del proceso que se les incoó a los varones implicados en semejantes tratos ilícitos, que la mujer prefería como pareja a quien ocupó el lugar de su esposo ${ }^{19}$. Esa voluntad declarada poco importaba en el marco ético de una época donde la mujer, como en este caso, podía fácilmente convertirse en moneda de cambio.

Ello es sólo una muestra del escaso peso que se le daba a la voluntad femenina en aquellos tiempos, carencia que a veces era fomentada por la propia maquinaria inquisitorial, que contribuía a convertir a las mujeres en mercancía de escaso valor.

Ése es también el caso de la joven hija de un secretario del Secreto sevillano que tuvo que casarse con quien sucedió en el cargo a su padre debido a que el inquisidor general Sarmiento de Valladares accedió a otorgar dicha plaza a quien consintiera contraer matrimonio con la joven, en atención a los deseos expresados por el progenitor de la misma.

No sabemos si sería la carencia de los encantos exigibles a las mujeres casaderas de la época lo que movió al padre de la novia para solicitar que se cumpliera esa condición. Pero seguro que la desposada por vía tan pintoresca no era precisamente falta de inteligencia, pues una vez viuda de quien sucedió a su padre se dirigió a la Suprema para solicitar que, debido a la pobreza en que había quedado tras el óbito, la plaza que el difunto dejara libre pudiera ser ocupada por su hijo.

La Inquisición, poco partidaria de la patrimonialización familiar de ese tipo de empleos, no accedió a sus deseos, asistiéndole en cambio, y según el estilo tuitivo que trataremos de manera especial más adelante, con otro tipo de ayudas económicas que vinieran a paliar su estado de necesidad $^{20}$.
${ }^{19}$ Ibid., p. 260.
${ }^{20}$ Ibid., pp. 258-259. 
Veamos a continuación otro aspecto relacionado con los supuestos que acabamos de traer a colación y que en ocasiones nada tiene que ver con la faceta oscurantista y represora de la Inquisición.

\section{LAS MUJERES Y SU VIDA COTIDIANA ANTE EL SANTO OFICIO}

\section{La mujer como beneficiaria de las ayudas sociales sufragadas por el Santo Oficio: la «Seguridad Social» de la Inquisición}

El aparato inquisitorial, por otro lado, era una maquinaria administrativa colosal que generaba innumerables colocaciones laborales para una nube de funcionarios asalariados y no asalariados. La situación personal o familiar en que se hallaban muchas mujeres indirectamente dependientes de las arcas inquisitoriales venía marcada por la enfermedad, discapacidad o incluso el fallecimiento de los varones que trabajaban para el Santo Oficio.

Existía una tradición consuetudinaria consolidada por prácticas inveteradas en el ámbito de cada tribunal de distrito por lo que respecta a las ayudas que deberían recibir esas féminas que se vieran afectadas por la falta de salud o el óbito de sus maridos cuando éstos habían sido empleados inquisitoriales. No encontramos en ningún otro ámbito social de la época una organización tan minuciosa en su actuación a la hora de intentar proveer a ese tipo de necesidades económicas acuciantes. Estos extremos han sido silenciados o se han ignorado de forma sistemática probablemente por no formar parte del aspecto oscurantista y represivo del Tribunal, mucho más llamativo a los ojos de ciertos estudiosos que el puro funcionamiento administrativo y burocrático del mismo.

Eran, insistimos, disposiciones de tipo consuetudinario que nunca se vieron reflejadas por el derecho escrito, pero nos atrevemos a asegurar que se trataba de un verdadero precedente de los más modernos sistemas de previsión social.

Son innumerables los documentos que se pueden encontrar dentro de los fondos del Archivo Histórico Nacional en los cuales las viudas de los trabajadores de la Inquisición solicitan ayudas económicas o viviendas para habitar con sus hijos en inmuebles pertenecientes al Santo Oficio ${ }^{21}$.

${ }^{21}$ M. J. Torquemada SÁncheZ, «Las funciones tuitivas del Santo Oficio», en Anuario de 
Las mujeres solían obtener esas ayudas previa instrucción de un expediente. Las féminas relacionadas con el Santo Oficio que resultaban desamparadas por la incapacidad o la muerte de un empleado suyo enviaban solicitud a la Suprema y ésta pedía información a los inquisidores del distrito donde aquél había prestado sus servicios. También informaba habitualmente el médico de la Inquisición, que no sólo asistía a los reos cuando se aplicaba tormento durante el procedimiento, sino que también atendía al personal inquisitorial, habitando dicho facultativo, en ocasiones, dentro de la propia sede de los tribunales en los que ejercía su profesión ${ }^{22}$. No se trataba necesariamente de viudas y huérfanas, pues tenemos constancia de alguna madre de empleado inquisitorial que solicitó se le proporcionara casa-habitación al fallecer su hijo ${ }^{23}$.

\section{La mujer, la Inquisición y la moda}

Otra cuestión en que se entremezclan Inquisición y feminidad es la referente al modo de vestir durante el periodo de existencia del Santo Oficio.

Los moralistas que habían alimentado la doctrina de la Iglesia al respecto siempre habían considerado el cuerpo de las mujeres como una permanente incitación ad turpia para los varones. La Inquisición no se mantuvo al margen de estas cuestiones y, una vez más, observamos ciertas diferencias en esos aspectos entre la metrópoli y las tierras americanas, donde por razones climáticas y tradicionales las vestimentas tendían a ser más livianas. El arzobispo Antonio de Berroeta publicó para la Iglesia peruana un edicto el 10 de octubre de 1754 referente a lo que él consideraba como vestimentas femeninas indecentes ${ }^{24}$.

Historia del Derecho español, t. LXVII, vol. II, pp. 1433-1445, esp. p. 1434.

${ }^{22}$ Ibid., p. 1435.

23 Ibid., p. 1440. Doña Antonia de Guzmán era madre de Esteban de la Peña y Guzmán, difunto secretario de la Inquisición sevillana. En 1709 solicitó que se le proporcionara alguna dependencia de la Inquisición donde pudiera habitar en atención al estado de suma pobreza en que había quedado tras la muerte de su hijo. La Suprema solicitó información al Tribunal de Sevilla acerca de la existencia de alguna vivienda libre en el Castillo de Triana, sede del tribunal, respondiendo éste que al momento no lo había, pero proponía otra solución, consistente en cederle a doña Antonia una casa propiedad del Santo Oficio que solía arrendarse pero que al momento se hallaba vacía. Si ninguna de estas soluciones era factible, la ayuda se materializaría en un dinero mensual con el fin de que la madre costeara otro arrendamiento (AHN, Inquisición, leg. 3024, caja 1, Carta de 15 de septiembre de 1709).

${ }^{24}$ R. Millar Carvacho, op. cit., pp. 186-187: «y ahora nos ha parecido no de menos 
No sólo las de carne y hueso estaban en el punto de mira eclesiástico e inquisitorial, sino también las imágenes de las iglesias con sus ropajes y adornos fueron puestas en entredicho.

La estética en la imaginería sacra, como es natural, había ido variando dependiendo de las épocas y lugares. Las autoridades civiles y religiosas durante el Antiguo Régimen cuidaban enormemente su apariencia externa, y existían normas al respecto de la indumentaria que se podía lucir según la posición o estamento que cada uno ocupara en la sociedad.

Naturalmente, la indumentaria de las mujeres se hallaba de algún modo estereotipada, como en todas las etapas de la Historia, pero no sólo atendiendo a las modas imperantes en cada momento y lugar, sino también a criterios de orden social que respondían a ciertas reglas morales.

La noción de lo que es decente, oportuno en el sentido etimológico de la palabra, trascendía de los comportamientos para extenderse también a los ropajes y adornos. Ello incidiría de plano sobre la moda femenina.

Poco tenía que decir la Inquisición respecto de la forma en que habían de vestir las mujeres, pues ello era, en principio, una cuestión baladí de la que se podrían ocupar las autoridades seculares mediante las consabidas leyes suntuarias, o, sencillamente, castigando el escándalo público en caso de indecencia manifiesta en el atuendo. Sin embargo, determinadas modas que no necesariamente implicaban la exhibición anatómica de las féminas se trasladaron sin remedio a las imágenes de las iglesias, trivializando su aspecto de tal modo que dejaban de servir a los fines para los cuales se habían esculpido o pintado: incitar a la piedad, al arrepentimiento, etc. En ese terreno es donde tomaría la Inquisición cartas en el asunto.

En efecto, podría suceder que los fieles, a la vista de esas tallas o esculturas ataviadas a la moda del momento, dejaran de ser iconos espirituales para convertirse en meros ídolos estéticos. Pero no eran estos últimos los valores que se pretendía mantener. En una sociedad mayoritariamente analfabeta las autoridades civiles y eclesiásticas, que en el caso español venían a ser la misma cosa, disponían de la imaginería como elemento importante para el adoctrinamiento de los súbditos. No había lugar para frivolidades.

indecencia, de vivo incentivo y de muy grande irreverencia, que traigan el pecho descubierto, particularmente cuando van a las iglesias y llegan al comulgatorio, pues con la acción de levantar el manto para recibir la Sagrada Forma descubren interioridades [...] muchos sabios y espirituales varones han declamado contra la desnudez de brazos y pechos y contra el demasiado adorno en cabeza y cara del otro sexo [...] cuya artificiosa hermosura ha sido causa de que muchos perezcan y que la concupiscencia tome pabulo». 
El Santo Oficio era el llamado a poner coto en semejantes excesos cuando éstos se produjeran, evitando cualquier desviación.

Lo mismo que se controlaban los escritos y otras manifestaciones culturales, se vigilaba la factura y apariencia de las imágenes que se hallaban expuestas en las iglesias.

Si bien la Inquisición actuó con bastante independencia en otras materias, separándose cuando le convenía de la tradición y la doctrina canónicas, en este caso secundó ambas, como ponen de manifiesto las Cartas Acordadas y otros documentos que se enviaban desde la Suprema a los tribunales de distrito.

En lo tocante a estos asuntos, tan relacionados con los diferentes gustos estéticos de cada territorio y debido al ingente y variopinto número de personas sobre los cuales el Santo Oficio ejercía su tutela, el aparato inquisitorial tropezó con verdaderos problemas a la hora de unificar criterios morales y estéticos ${ }^{25}$.

Existía una larga trayectoria canónica que fue asumida por el aparato inquisitorial a la hora de controlar estos asuntos, pues desde los tiempos de la herejía iconoclasta numerosos concilios se habían ocupado de ello ${ }^{26}$, y era lógico que el aparato inquisitorial, omnipresente en los distintos aspectos de la vida de cualquier católico, asumiera competencias al respecto.

Encontramos, a modo de ejemplo, un edicto elaborado por la Inquisición siciliana siguiendo las pautas marcadas por un modelo anterior generado por la Suprema, que había circulado entre los distintos tribunales de distrito, tendente a salir al paso de la aparente anarquía existente en el modo de ataviar las figuras sacras que se exhibían en los templos del orbe hispánico. Ambos documentos, aunque no hacen constar una fecha concreta, pueden datarse en torno a 1640 .

El edicto del Consejo de Inquisición, que no es más que otra de las manifestaciones de la censura inquisitorial, abarcaba tanto a las manifestaciones pictóricas como escultóricas, y se lamentaba especialmente de las indumentarias con que se exhibía la figura de la Virgen. De nuevo las formas femeninas en el punto de mira.

Esa norma expedida por el Consejo constaba de una exposición de $\operatorname{motivos}^{27}$ y el cuerpo del edicto propiamente dicho con las prescripcio-

${ }^{25}$ M. J. Torquemada Sánchez y J. A. Alejandre García, «Vestir Santos. Un asunto de Inquisición y su reflejo en Sicilia», en Cuadernos de Historia del Derecho, núm. 8, 2001, pp. 257-270.

26 Ibid., pp. 261-267.

${ }^{27}$ Ibid., pp. 259-260. AHN, Inquisición, libro 1252, fol. 221: «Como sea obligación de 
nes que se debían poner en práctica ${ }^{28}$. En términos generales, se ordenaba retirar determinados ropajes y ornamentos que se consideraban mundanos e incitantes a la concupiscencia, ofreciendo una enumeración breve de los mismos que, en consonancia con la deliberada indeterminación que caracterizaba los mandatos inquisitoriales, dejaba abierto el elenco de lo que había que suprimir, y al arbitrio de los inquisidores de cada distrito las medidas al respecto cuando considerasen impropios algunos elementos que no se especificaban en el edicto.

El mandato surtía efecto desde el momento de su recepción por los tribunales. Conocemos la forma en que el tribunal siciliano dio cumplimiento al edicto y que, en efecto, lo asumió como mera directriz, publicando otro mucho más minucioso en el que además se ampliaba el elenco de prendas prohibidas y se hacía alusión expresa a la normativa vigente en esas materias $^{29}$. Además, volvemos a constatar que, aún refiriéndose este edicto para Sicilia tanto a la figura de Cristo como de la Virgen y otros personajes sagrados, incide especialmente en las prendas y adornos femeninos ${ }^{30}$.

El índice de Quiroga de 1583 fue el primero en abordar este tipo de cuestiones, seguramente para reflejar en él la recién creada doctrina tridentina, que abordó el asunto de las imágenes como respuesta contundente a las teorías protestantes. Luego aparecerían prescripciones que reprodu-

nuestro ministerio y de la delegación apostólica que ejercemos el reformar en los vestidos de las Sagradas y Venerables imágenes todos los abusos profanos que puedan causar escándalo a los fieles. Porque sirviendo la pintura en los ignorantes para los mismos efectos que en los doctos la escritura, adorando en ellas y aprendiendo lo que los entendidos comprenden por escrito con el recuerdo y memoria de las acciones y gloria de los Santos a quien representan, reforzándose los cristianos en los artículos de nuestra Santa Fe, teniéndolos por ejemplares [...] hemos observado con gran sentimiento nuestro que en las Iglesias y Altares públicos y privados de poco tiempo a esta parte, contra los prohibido por los sagrados cánones, concilios y reglas de nuestro expurgatorio, se ha introducido exponer la imagen del Niño Jesús y de su Purísima e Inmaculada Madre con hábito mundano y desigual a su vida y acciones. Y porque este modo de vestidos no sea objeto de profanidad, ocasión de errores ni motivo de irreverencia».

${ }^{28}$ Ibid., p. 260: «Ordenamos y mandamos que de las imágenes sagradas se quite totalmente cualquier género de abuso que pueda motivar superstición, sensualidad o que repugne a su santidad, vida y acciones, como son enaguas, guardainfante, copete, guedejas, ligas, roseta y otros abusos semejantes con que como este nuestro Edicto llegue a Vuestra noticia sopena Vuestra».

${ }^{29}$ AHN, Inquisición, libro 1252, fol. 217 y ss.

30 Ibid.: "Prohibemo e dannamo quasivoglia sorte di vestimento e habito indecente e vano col quale si vestono le statue di Nostro Signore, de Nostra Signora sua Madre e degl'altri santi, cioe guardanfantio, veste con scollatura e apertura lasciva e mundana inventata modernamente dalla gente mondana per vanita e lascivia [...] ma qui non se metano all'orechie pendaglie di niuna sorte ne anco si metta in testa cabellera con capella ritorti e troppo sopra la frente». 
cían literalmente lo preceptuado en el anterior dentro de los de Sandoval y Zapata. En dicho índice de Quiroga es la regla duodécima, y no la undécima, como reza el documento siciliano, la que prohíbe cualquier manifestación en la cual se conviertan las imágenes en objetos de carácter mundano, lejos de la espiritualidad y recogimiento que deben inspirar a los fieles ${ }^{31}$.

Conviene resaltar que en toda esta doctrina y legislación inquisitorial era el atuendo de la mujer y no el de los varones, como puede observarse a juzgar por los ropajes y complementos de moda que resultaban prohibidos en las imágenes de forma expresa, el que se hallaba bajo permanente sospecha de heterodoxia.

\section{CONCLUSIONES}

A la vista de los diferentes aspectos examinados, puede inducirse que la Inquisición hispánica aplicaba la normativa que regía su funcionamiento de manera diferente atendiendo al factor diferencial que marcaba el sexo de los individuos que entraban en contacto con tan temible institución.

En las presentes líneas hemos aludido a la feminidad como elemento del que se parte a la hora de distinguir varios aspectos jurídicos del ámbito inquisitorial, no resultando todos ellos negativamente discriminatorios para las mujeres, sino que, por el contrario, particularmente en lo tocante a la aplicación procesal del tormento y a las sanciones de contenido físico, resultaba netamente beneficiada en comparación con los varones.

También en otros terrenos, cual es el de las ventajas tuitivas que se derivaban de la adscripción de ciertos sujetos al Santo Oficio en calidad de empleados de la institución, resultaban notoriamente favorecidas las mujeres relacionadas con éstos en calidad de hijas, madres, esposas, etc., accediendo con mucha frecuencia a ciertas ayudas sociales consuetudinariamente otorgadas cuando esos trabajadores, por muerte, enfermedad o vejez, ya no podían mantenerlas.

31 AHN, Biblioteca, 2172, Index et catalogus librorum probibitorum, mandato illustris ac Reverendis D. D. Gasparis Quiroga, Madrid, 1583, pp. 5-6, regla duodécima: «Assi mesmo se prohibe todas y cualesquier imágenes, retractos, figuras, monedas, empresas, invenciones, maxcaras, representaciones y medallas, en cualquier materia que esten estampadas, pintadas, debuxadas, labradas, texidas, figuradas o bechas que sean en irrision de los sanctos, y en desacato e irreverencia suya y de sus imágenes y reliquias o de sus milagros, babito, profesion o vida. Y asi mesmo las que fueren en desacato de la Santa Sede Apostolica, de los Romanos Pontifices, Cardenales y Obispos y de su estado, orden, dignidad y autoridad, claves y poderio espiritual». 
Sin embargo, si descendemos a la consideración social de la mujer que subyace en toda la construcción socio-jurídica generada por la Inquisición española, la desconfianza en sus capacidades y la sospecha sistemática acerca de sus cualidades morales e intelectuales deja mucho que desear. Pero ello no es una peculiaridad de la perspectiva con que la contemplaba el Santo Oficio, sino de la mentalidad dominante durante todo el Antiguo Régimen, heredada, por otra parte, de planteamientos muy anteriores que ya se hicieron patentes desde tiempos tan remotos como los de la Roma clásica, cuya sociedad patriarcal se encargó de grabar a fuego en todos los ordenamientos jurídicos occidentales el menoscabo del género femenino como sujeto de derechos y obligaciones.

Tras la desaparición de la Inquisición Española en 1834, los condicionantes sexistas continuaron vigentes dentro de otras parcelas del ordenamiento jurídico español, siendo relativamente muy recientes los intentos de los legisladores conducentes a su eliminación. 